Article

\title{
The Temporal and Spatial Differentiation Characteristics of Three Industry Convergence Development in Deeply Impoverished Areas in China
}

\author{
Na Zhang ${ }^{1,2}$, , Xiangxiang Zhang ${ }^{1}$ and Peng $\mathrm{Li}^{3, *(1)}$ \\ 1 School of Economics and Management, Shihezi University, Shihezi 832000, China; \\ zhangnanuaa@163.com (N.Z.); Zhangxjan@163.com (X.Z.) \\ 2 Guanghua School of Management, Peking University, Beijing 100871, China \\ 3 College of Economics and Management, Jiangsu University of Science and Technology, \\ Zhenjiang 212003, China \\ * Correspondence: jellyok@126.com; Tel.: +86-186-5140-5640
}

Received: 27 November 2019; Accepted: 15 January 2020; Published: 22 January 2020

\begin{abstract}
The integrated development of the three industries is the focal point and breakthrough point for the realization of industrial poverty alleviation in the deeply impoverished areas. This paper, taking 169 poverty-stricken counties in deeply impoverished areas as the research object, calculated the level of three industrial integration development in deeply impoverished areas from 2013 to 2016. Based on this, the spatial statistical analysis method was used to explore the spatial and temporal differentiation characteristics of the three industrial integration development levels in deeply impoverished areas. The results show that the level of integrated development of the three industries in the deeply impoverished areas of China is generally low, and there is great room for improvement. There are significant spatial correlation and spatial heterogeneity, and the phenomenon of bipolar agglomeration is more and more obvious. This study can provide a theoretical basis and decision-making reference for the formulation and implementation of poverty alleviation policies in deeply impoverished areas.
\end{abstract}

Keywords: deeply impoverished areas; three industry convergence; development level; time and space differentiation

\section{Introduction}

Since the reform and opening-up, China has gone from "the national economy to the brink of collapse" to the second-largest economic entity in the world. China's achievements in economic construction have attracted worldwide attention. Since the reform and opening-up in 1978, the growth rate of China's economy has been fluctuating with distinct stages. From 1978 to 1991, this period was the transition period of China's economy. The macroeconomic thought had completed the transition from the "comprehensive balance" to the "macro-control" paradigm, and the fluctuations in monetary growth were most obvious at this time. From 1992 to 1997, China's economy developed at a fairly brisk pace, the socialist market economy system was basically established, and the idea of macro-control was basically formed and successfully applied. From 1998 to 2002, China suffered from the Asian financial crisis, and its economic growth was delayed to some extent. From 2003 to 2012, China's economy recovered and developed at a high speed. Since 2013, China's economy has shifted from extensive growth of scale and speed to intensive growth of quality and efficiency, and China's economic development has entered a new routine (GDP and its growth rate are shown in Figure 1). At present, China's economy is in the midst of a transition period, and its industrial structure has yet to be adjusted. In the process of economic transformation, the Central and Eastern European countries, especially 
Poland, the Czech Republic, and Hungary, continued to decline in the proportion of total agricultural and industrial output value, and the proportion of total output value of the service industry continued to increase, which provided valuable experience for the transformation and upgrading of China's industrial structure [1].

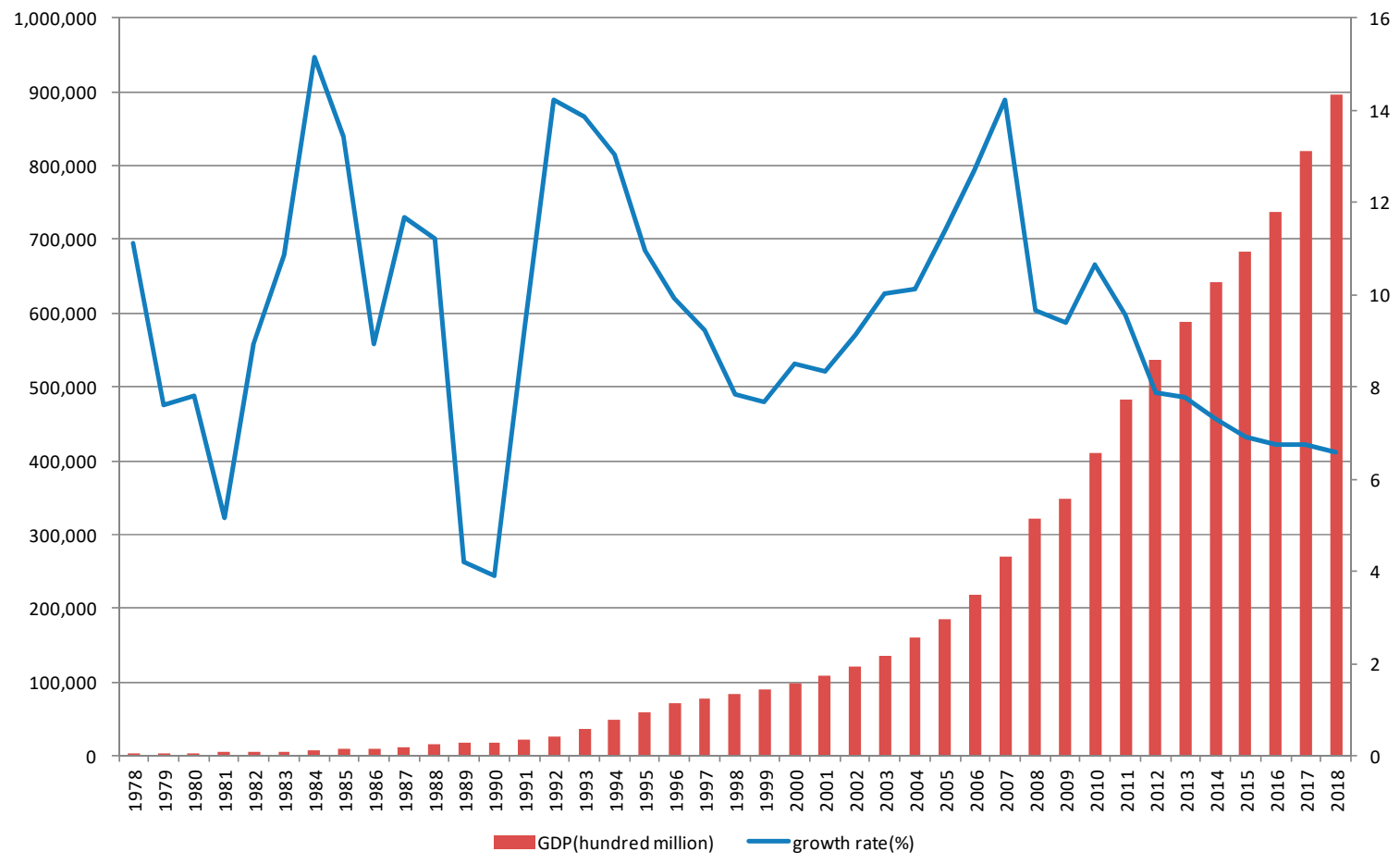

Figure 1. China's GDP and its growth rate from 1978 to 2018.

Under the new normal, the process of value creation is gradually changed by intelligence, networking, deregulation and innovative management, so that the industrial structure boundary within the same industry or between different industries gradually fades, blurs, or even disappears. As a new trend of modern industrial development, the integration of three industries is a new industrial development mode that promotes traditional industries to seek new development and expand and extend, promotes the optimization and upgrading of traditional industrial structure, meets higher level of consumer demand, and gives new vitality to industrial development [2]. A reasonable industrial structure can effectively allocate resources, promote economic growth, and bring new development opportunities to the deeply poor areas, so as to help the deeply poor areas get rid of poverty by relying on industry and realize the sustainable development of regional economy and society.

Rosenberg put forward the idea of industrial integration [3], and then scholars continued to study the attributes, types [4], and effects [5] of industrial integration. Greenslein believed that the industry convergence triggered by digital technology makes the previously independent industry change from vertical development to horizontal development and gradually extend to other industries [6]. Stieglitz mainly analyzed industrial integration due to government deregulation $[7,8]$. In addition, scholars explored industrial integration from the aspects of the telecom industry [9], manufacturing industry and service industry [10], cultural industry and tourism [11], cross-border electricity and logistics [12] and exploring the business model innovation of the APPLE (Cupertino, CA, USA) company with the world's strongest technological innovation capability in the process of industrial integration [13]. Up to now, it is widely accepted that industry convergence is a dynamic development process of knowledge, technology, products, and market between different industries from being independent to continuously cross and penetrate, gradually breaking through the industrial boundary and forming new formats $[14,15]$. Because the industrial integration is a new 
trend for the development of modern industry, the research perspectives focused on tourism and cultural industry $[16,17]$, industrialization and informatization $[18,19]$, information technology and manufacturing [20,21], equipment manufacturing industry and producer services [22,23], and other areas of the two-dimensional integration, as well as cultural [24], logistics [25], and tourism [26]. As for the research contents, scholars main delve into industrial integration development motivation [27-29], mechanism [30,31], and path [26,32]. In terms of measurement methods, it mainly includes the fusion coefficient method [18], DEA [33], Herfindahl index method [34], input-output method [35], comprehensive index method [24] and other methods. It is found that industrial integration can encourage the development of traditional industries, and the optimization, upgrading, and adjustment of industrial structure.

Research on industry convergence in the academic circles is mainly focused on the connotation, classification, motivation, and other segments of industry empirical and other aspects. At present, the research perspective is mainly focused on the integration of one industrial section and two industrial sections, which have not been extended to the three-dimensional space of primary, secondary and tertiary industries integration. Moreover, the research object is basically at the level of provinces and cities, which rarely involve the deeply impoverished counties. In addition, the measurement method of industrial integration is one-sided and subjective, and a unified, scientific, comprehensive, and accurate measurement method has not been formed. At present, scholars mostly focus on qualitative research of industrial integration, such as motivation, type, optimization path, and mechanism, and pay less attention to the characteristics of spatial distribution and evolution.

The related literature on the spatial distribution and evolution of industrial convergence is mainly concentrated in the EU or Central Europe [35-39]. Based on the results of other studies, this paper, by means of the entropy and spatial autocorrelation analysis method, makes an objective measurement of the development level and trend of three industrial integration in China's 169 deep-poverty counties, and analyzed the time and space distribution characteristics and the dynamic change trend, so as to provide the relevant theoretical basis for poverty alleviation in China (the method and the related measures as shown in Table 1).

Table 1. Comparison of the methods in this paper and related methods of industrial integration.

\begin{tabular}{cl}
\hline \multicolumn{1}{c}{ Methods } & \multicolumn{1}{c}{ Characteristics } \\
\hline fusion coefficient method & $\begin{array}{l}\text { By examining the correlation coefficient of patent shares among selected } \\
\text { industries and judging the degree of industrial integration through the } \\
\text { change of correlation coefficient matrix, it is not suitable for the research at } \\
\text { the macro level }\end{array}$ \\
\hline DEA & $\begin{array}{l}\text { The efficiency of industrial integration is measured by the input-output } \\
\text { index of each industry }\end{array}$ \\
\hline Herfindahl index method & $\begin{array}{l}\text { The degree of industrial integration can be calculated by the sum of the } \\
\text { square proportions of the revenue or assets of each competitive entity in an } \\
\text { industry and the total of the industry, but the problem of multicollinearity } \\
\text { cannot be solved }\end{array}$ \\
\hline input-output method & $\begin{array}{l}\text { The input coefficient reflects the direct consumption of other products in the } \\
\text { production process of an industry, which is a one-way connection. Its } \\
\text { accuracy is largely affected by the availability of data }\end{array}$ \\
\hline comprehensive index method & $\begin{array}{l}\text { The analytic hierarchy process (AHP) is used to calculate the weights and } \\
\text { take the product with the index data }\end{array}$ \\
\hline $\begin{array}{l}\text { The entropy method is decomposable and can solve the problem of } \\
\text { autocorrelation analysis } \\
\text { method }\end{array}$ & $\begin{array}{l}\text { The spatial autocorrelation method can be used to study the agglomeration } \\
\text { relation and spatial distribution characteristics of three industries in deep } \\
\text { poverty areas based on the entropy measure }\end{array}$ \\
\hline
\end{tabular}




\section{Index System and Research Method}

Industrial division is a process of decomposing and combining all kinds of activities that constitute the national economy according to certain standards to form multi-level industrial categories. By far the most influential is the third industry classification method of Fisher and Clark [40,41]. On the basis of this theory, American economist Simon. S. Kuznets similarly applied Clark's three-industry division to various sectors of the national economy, including agriculture, industry, and service (AIS division method) [42]. In 1977, Borat proposed a quartile of industrial division, that is, to separate the digital industry from the service industry. The entire national economy is comprised of industry, agriculture, service industry, and digital industry. The digital industry is what people call the fourth industry [43]. In recent decades, some economists in the United States, Japan, and other countries began to propose the concept of the fifth industry after the concept of the fourth industry, but there is no definite explanation. Based on Japanese culture, the fifth industry generally refers to the service industry centered on spiritual enjoyment, entertainment, and psychological stimulation, and its scope includes entertainment, fun, fashion, beauty, and tourism, etc. On 14 May 2003, the National Bureau of Statistics of China issued the "Regulations on the Division of the Three Industries" in the national statistical system and various departments of the State Council, announcing the new scope of the three industries. Primary industry refers to agriculture, forestry, animal husbandry, and fishery. Secondary industry refers to the mining industry, manufacturing, power and gas and water production and supply, and construction. The tertiary industry refers to additional industries except for the primary and secondary industries [44]. Relevant statistical data in China is also dependent on the provisions on the division of tertiary industries. Therefore, although the method of division of tertiary industries can no longer fully reveal the changes in the national economic structure caused by the wave of a new technological revolution in the world, such division is still widely followed both abroad and in China.

Agriculture is the foundation of healthy economic development in deeply impoverished areas. At the same time, agriculture, as the material basis of other industries, can provide production factors for other industries. Service industry can promote the level of agricultural modernization and industrial transformation and upgrading. To a certain extent, industry and service industry are the expansion of modern agriculture. Therefore, it is of great significance to establish a corresponding index system based on the provisions on the division of the three industries in China and explore the level of integrated development among the three industries through agriculture, industry, and service industry.

\subsection{Index System Construction and Data Sources}

On 23 June 2017, Xi Jinping, General Secretary of the CPC Central Committee, State President, and Chairman of the Central Military Commission, hosted a symposium on poverty alleviation in deep poverty areas and delivered an important speech. Make deployment arrangements for tackling tough times. In November 2017, the General Office of the Central Committee of the Communist Party of China and the General Office of the State Council issued the "Implementation Opinions on Supporting Poverty Alleviation in Deeply Impoverished Areas", stating that Tibet, the four provinces of Tibet, the four provinces of southern Xinjiang, the Liangshan Prefecture of Sichuan, and the Nujiang Prefecture of Yunnan, Linxia Prefecture, Gansu Province, and poor counties with a poverty incidence rate of more than $18 \%$ and poor villages with a poverty incidence rate of more than $20 \%$. Poor natural conditions, weak economic foundations, and deep poverty are the main challenges in poverty alleviation. It is the key strategy for the decisive fight against poverty, so it is called a deep poverty area. Deep-poverty counties are in the scope of deep poverty areas.

In this paper, 169 deep-poverty counties from the "three districts and three prefectures" are studied, including 32 counties of the four prefectures in southern Xinjiang, 23 counties of Qinghai Province, 14 counties of Gansu Province, 67 counties of Tibet, 3 counties of Yunnan Province and 30 counties of Sichuan Province. Since China started its targeted poverty alleviation work in 2013, the relevant data in the current yearbook has only been updated to 2016. Considering the background of targeted poverty alleviation work and the availability of data, 2013-2016 was selected as the evaluation sample. 
As for the measurement of the level of the three industry convergence, the construction of the index system is a fundamental basis. In the existing studies on industrial integration, it calculated the level of agricultural development in China [45]. Taking Hubei Province as an example, it evaluated the level of agricultural development with indicators such as farmers' per capita income, grain output per unit sown area, agricultural per capita GDP and effective irrigation rate [46]. It evaluated the industrialization of Jilin Province by establishing relevant indicators [47]. It used industrial added value to measure industrial development [48]. It measured the development level of the service industry by using per capita GDP, the proportion of the added value of the service industry, the added value of the service industry, and growth rate indicators [49]. It set up an indicator system of integrated development of three industries [50]. It used economic growth, industrial restructuring, and labor market skills to build industrial integration indicators [51-54]. Based on the connotation of the integration of three industries and relevant research results, the evaluation index system of the integration of three industries in deeply impoverished areas is finally constructed under the principles of scientific nature, feasibility, and data availability (as shown in Table 2). The data in this paper are from China County Statistical Yearbook and relevant provincial statistical yearbook, and some missing data are complemented by the annual average growth rate method.

Table 2. Evaluation index of integrated development of three industries in deeply impoverished areas.

\begin{tabular}{|c|c|c|c|c|c|}
\hline $\begin{array}{l}\text { The First } \\
\text { Level Index }\end{array}$ & Weight & $\begin{array}{l}\text { The Second Level } \\
\text { Index }\end{array}$ & Calculating Method & Weight & $\begin{array}{l}\text { Index } \\
\text { Attribute }\end{array}$ \\
\hline \multirow{5}{*}{ Agriculture } & \multirow{5}{*}{$1 / 3$} & $\begin{array}{l}\text { Per capita income of } \\
\text { rural residents }\end{array}$ & Per capita income of rural residents & 0.217 & Positive \\
\hline & & $\begin{array}{l}\text { Agricultural } \\
\text { mechanization level }\end{array}$ & $\begin{array}{c}\text { Total power of agricultural } \\
\text { mechanization/agricultural arable } \\
\text { land }\left(\mathrm{kw} / \mathrm{hm}^{2}\right)\end{array}$ & 0.157 & Positive \\
\hline & & $\begin{array}{c}\text { Per unit area yield } \\
\text { of grain }\end{array}$ & $\begin{array}{c}\text { Total grain output/area sown to } \\
\text { grain }\left(\mathrm{kg} / \mathrm{hm}^{2}\right)\end{array}$ & 0.172 & Positive \\
\hline & & $\begin{array}{l}\text { Effective irrigation } \\
\text { rate for agriculture }\end{array}$ & $\begin{array}{c}\text { Available irrigated area/agricultural } \\
\text { arable area }(\%)\end{array}$ & 0.176 & Positive \\
\hline & & $\begin{array}{l}\text { Rural Engel } \\
\text { coefficient }\end{array}$ & $\begin{array}{l}\text { Food expenditure/consumer } \\
\text { expenditure of rural residents (\%) }\end{array}$ & 0.271 & Negative \\
\hline \multirow{5}{*}{ Industry } & \multirow{5}{*}{$1 / 3$} & $\begin{array}{c}\text { Rate of } \\
\text { industrialization }\end{array}$ & Industrial added value/GDP (\%) & 0.149 & Positive \\
\hline & & $\begin{array}{l}\text { Profit margin of } \\
\text { industrial output }\end{array}$ & Total industrial profits/output value & 0.174 & Positive \\
\hline & & $\begin{array}{c}\text { Industrial } \\
\text { productivity }\end{array}$ & $\begin{array}{l}\text { Industrial added value/employees } \\
\text { (ten thousand RMB/person) }\end{array}$ & 0.240 & Positive \\
\hline & & $\begin{array}{l}\text { Contribution rate of } \\
\text { total assets }\end{array}$ & $\begin{array}{c}\text { (total profit and tax }+ \text { interest } \\
\text { expense)/total average assets (\%) }\end{array}$ & 0.187 & Positive \\
\hline & & $\begin{array}{l}\text { Ratio of foreign } \\
\text { investment }\end{array}$ & $\begin{array}{l}\text { Investment by foreign } \\
\text { enterprises/Total industrial output } \\
\text { value above scale }\end{array}$ & 0.250 & Positive \\
\hline \multirow{5}{*}{$\begin{array}{l}\text { service } \\
\text { industry }\end{array}$} & \multirow{5}{*}{$1 / 3$} & GDP per capita & GDP/total population (RMB) & 0.173 & Positive \\
\hline & & $\begin{array}{l}\text { Output level of } \\
\text { service industry }\end{array}$ & $\begin{array}{c}\text { Growth rate of output value of } \\
\text { service industry }(\%)\end{array}$ & 0.194 & Positive \\
\hline & & $\begin{array}{l}\text { The proportion of } \\
\text { output value of } \\
\text { service industry }\end{array}$ & $\begin{array}{l}\text { The added value of the service } \\
\text { industry/GDP in the area (\%) }\end{array}$ & 0.190 & Positive \\
\hline & & $\begin{array}{l}\text { Total value of service } \\
\text { industry }\end{array}$ & $\begin{array}{c}\text { Total value of service industry (One } \\
\text { hundred million RMB) }\end{array}$ & 0.233 & Positive \\
\hline & & $\begin{array}{l}\text { The proportion of } \\
\text { service industry } \\
\text { investment }\end{array}$ & $\begin{array}{c}\text { Fixed assets investment in the } \\
\text { service industry/total fixed assets } \\
\text { investment }(\%)\end{array}$ & 0.210 & Positive \\
\hline
\end{tabular}




\subsection{Research Method}

\subsubsection{Entropy Method}

The entropy method determines the weight of each index in the whole system according to the information entropy of the index, which is more reliable and accurate in the comprehensive evaluation of multiple objects and indexes than subjective weight [55]. Because the entropy method can deeply reflect the utility value of the index information entropy value and determine the weight, this idea is very similar to the three industry convergence development system. The three industry index is the most important factor affecting the development of the three industry convergence. The factor with the greatest degree of change is a more objective method of empowerment that can avoid the subjectivity of artificial empowerment. The entropy method is used to calculate the weight of the evaluation index (see the weight part of Table 2), the comprehensive evaluation result of the integrated development of the three industries is finally obtained through information aggregation. The specific steps are as follows:

Dimensionless processing: Due to the different dimensionality of the original data of each index, the range method is adopted to conduct a linear transformation on the index data, so that the result can be mapped to the interval of $[0,1]$. The specific standardization formula is as follows:

$$
\begin{aligned}
& \text { Positive index : } y_{i j}=(1-\alpha)+\alpha \cdot\left(x_{i j}-x_{j \min }\right) /\left(x_{j \max }-x_{j \min }\right) . \\
& \text { Negative index: } y_{i j}=(1-\alpha)+\alpha \cdot\left(x_{j \max }-x_{i j}^{\prime}\right) /\left(x_{j \max }-x_{j \min }\right) .
\end{aligned}
$$

wherein, $y_{i j}$ is the value after dimensionless treatment, $x_{i j}\left(x_{i j}^{\prime}\right)$ is the actual value of the $j$ th index of the poor county $i$, and $\alpha$ is the adjustment coefficient which is generally set as 0.9 .

Entropy method to solve the weight $W_{j}$

$$
W_{j}=\frac{1+\frac{1}{\ln m} \sum_{i=1}^{m} p_{i j} \cdot \ln p_{i j}}{\sum_{j=1}^{n}\left[1+\frac{1}{\ln m} \sum_{i=1}^{m} p_{i j} \cdot \ln p_{i j}\right]}
$$

wherein, $p_{i j}=y_{i j} / \sum_{i=1}^{m} y_{i j}$ is the proportion of the index $j$ of the poor county $i, W_{j}$ is the entropy weight of the index $j$.

Measure function of three industries integration level in poverty-stricken areas

$$
U_{t}=\sum_{i=1}^{n} W_{j} \cdot Y_{i j}, t=1,2,3
$$

wherein, $j$ is the number of indicators of a system, $W_{j}$ is the weight of indicators, $Y_{j}$ is the standardized value of the index $j$ in the $i$ th year, and $U_{1,2,3}$ is the measure value of the integration level in the agriculture, industry, and tertiary industry.

\subsubsection{Spatial Auto-Correlation Analysis}

Spatial auto-correlation analysis explores spatial characteristics through the correlation relationship between geographical location and research attributes and describes the clustering or dispersion phenomenon of the observed object's element attributes in a certain spatial range mainly through global auto-correlation coefficient and local auto-correlation coefficient [56]. Is there a certain spatial agglomeration effect in the three industrial integration developments in deeply impoverished counties? The spatial autocorrelation model can answer this question through the global Moran 's I index and local Moran's I index, and it can analyze the characteristics of its spatial distribution, and propose the 
direction of industrial structure adjustment for the main problems facing the development levels of various regions.

\section{(1) Global Moran's I index}

In this paper, the global Moran's I index is adopted to judge the correlation and different degrees of the integrated development of the three industries in the adjacent poor counties. The calculation formula is as follows:

$$
I=\frac{\sum_{i=1}^{n} \sum_{j \neq i}^{n} w_{i j}\left(x_{i}-\bar{x}\right)\left(x_{j}-\bar{x}\right)}{S^{2} \sum_{i=1}^{n} \sum_{j \neq i}^{n} w_{i j}}
$$

wherein, $I$ is the global Moran's I, $x_{i}$ represents the level of integrated development of the three industries in the poverty-stricken county, $S^{2}=\frac{1}{n} \sum_{i=1}^{n}\left(x_{i}-\bar{x}\right)^{2}, \bar{x}=\frac{1}{n} \sum_{i=1}^{n} x_{i}, w_{i j}$ is the spatial weight, which is generally expressed as $\mathrm{N}$-dimensional matrix $W(n \times n)$, and is usually determined by the spatial adjacency and spatial distance matrix.

This study applies the spatial adjacency mode based on Rook, that is, if the poor county $i$ and the poor county $j$ belong to the adjacency relationship, then $w_{i j}=1$, or $w_{i j}=0$. The value range of global Moran's I is $[-1,1]$. If $I>0$, there is a positive spatial correlation, which means the poor counties with high (low) tertiary industry convergence tend to gather in space. If $I<0$, there is a negative spatial correlation, which means there is a spatial difference in the industry integrated development between this county and its adjacent counties. If $I=0$, the space is irrelevant, which means the integrated level of three industries in poverty-stricken counties is randomly distributed in space.

\section{(2) Moran scatter diagram [56]}

In order to further measure the local spatial characteristics of each poverty-stricken county and its surrounding poverty-stricken counties, Moran scatter map can well describe the local spatial distribution. The Moran scatter plot takes the observed value $y$ and the spatial hysteresis vector $\mathrm{W}$ as the horizontal and vertical coordinates, respectively, and visually shows the spatial aberration and local imbalance in a two-dimensional plane. The scatter diagram contains four quadrants representing four spatial distribution. The first and third quadrants represent spatial agglomeration. The second and fourth quadrants represent spatial differentiation.

\section{(3) LISA cluster map}

LISA means local indicators of spatial association. Global spatial autocorrelation explains whether there is agglomeration (H-H, L-L) in the study area, while local spatial autoregression explains its specific spatial position and the significance of the agglomeration. In the LISA map, clustering is divided into four cases, each of which identifies a region and its relationship with its neighbors.

\section{(4) Local Moran's I index}

Moran scatter plot cannot determine whether the local spatial characteristics of the study objects have passed the statistical significance test, while the local Moran's I index can. Its calculation formula is as follows:

$$
I_{i}=z_{i} \sum j W_{i j} z_{j}
$$

wherein, $z_{i}$ and $z_{j}$ are the standardized variables of spatial observations for mean and standard deviation respectively. If $I_{i}>0$, then the industrial integration of the poor county is similar to that of the adjacent counties, which are in the form of a high-high cluster or a low-low cluster. If $I_{i}<0$, then the industry convergence of the poor county is different from that of the adjacent counties, which are in the form of high-low cluster or low-high cluster. 


\section{Results and Discussion}

3.1. Comprehensive Evaluation and Analysis of the Integrated Development of Three Industries in Deeply Impoverished Areas

The comprehensive integration development level and classification (proportion) of the three industries in the deeply impoverished areas from 2013 to 2016 are respectively obtained by the entropy weight method, as shown in Table 3.

Table 3. Comprehensive level of industry convergence in deeply impoverished areas.

\begin{tabular}{|c|c|c|c|c|c|}
\hline Year Classification & $\mathrm{U} \geq \mathbf{0 . 5}$ & $0.4 \leq \mathrm{U}<0.5$ & $0.3 \leq \mathrm{U}<0.4$ & $0.2 \leq \mathrm{U}<0.3$ & $0.1 \leq \mathrm{U}<0.2$ \\
\hline 2013 & $1(1.18 \%)$ & $4(2.37 \%)$ & $42(25.44 \%)$ & $118(68.64 \%)$ & $4(2.37 \%)$ \\
\hline 2014 & $0(0)$ & $8(5.33 \%)$ & $48(27.22 \%)$ & $112(66.86 \%)$ & $1(0.59 \%)$ \\
\hline 2015 & $0(0)$ & $4(2.96 \%)$ & $108(63.31 \%)$ & $57(34.32 \%)$ & $0(0)$ \\
\hline 2016 & $0(0)$ & $2(1.78 \%)$ & $59(34.32 \%)$ & $108(63.91 \%)$ & $0(0)$ \\
\hline
\end{tabular}

In terms of the overall level of industry convergence in the deeply impoverished areas, among the 169 counties in 2013, Aksu city of Xinjiang had the highest comprehensive level, followed by Xichang city of Sichuan Province (0.4773), and Zhiduo County of Qinghai Province had the lowest comprehensive level (0.1800). This shows that the level of industry integrated development in the deeply impoverished areas is quite different from the whole. Thanks to development policies such as Western Development, Aid to Xinjiang, Targeted Poverty Alleviation, etc., after two years of development, among the 169 deeply impoverished counties in 2016, Huili County in Sichuan Province had the highest comprehensive level (0.4584), followed by Aksu city in Xinjiang Province (0.4439), and Zhiduo County in Qinghai Province had the worst comprehensive level (0.2011). Compared with 2013, the maximum value of the integrated development level is lower, while the minimum value is larger. Therefore, the overall difference between the integrated development level of the three industries in 2016 is narrowing, which is a kind of positive progress. The number and proportion of poverty-stricken counties at all stages of comprehensive development level are analyzed the same as in 2013, which will not happen again here.

\subsection{Overall Spatial Statistical Analysis of the Industry Integrated Development Level in the Deeply Impoverished Areas}

In order to further explore the spatial distribution characteristics of the integrated development, GeoDa software was used to calculate the global Moran's I value of the industry integrated development in deeply impoverished areas of China, as is shown in Table 4.

Table 4. Overall Moran's I for industry integrated development level in deeply impoverished areas.

\begin{tabular}{ccccc}
\hline Index & $\mathbf{2 0 1 3}$ & $\mathbf{2 0 1 4}$ & $\mathbf{2 0 1 5}$ & $\mathbf{2 0 1 6}$ \\
\hline Moran's I & 0.1486 & 0.2478 & 0.1951 & 0.2993 \\
Z & 3.0487 & 4.5703 & 3.7965 & 5.4555 \\
P & 0.0030 & 0.0010 & 0.0010 & 0.0010 \\
\hline
\end{tabular}

Notice: (1) Statistical inference in the table is based on 999 random permutations proposed by Ansen Lin. (2) The global expected value of Moran's I in all years is: $\mathrm{E}[\mathrm{I}]:=-0.0060$.

In Table 4, the global Moran's I values from 2013 to 2016 were all above 0 and passed the significance level of at least $1 \%$, which indicates that the areas with a higher integration level and those with a lower integration level show a bipolar agglomeration and distribution trend with spatial correlation. This may prove to be a convergence effect between poor counties. That is, the level of integrated industrial development of a poor county depends on the integrated industrial development of adjacent poor counties, and this kind of proximity effect is more and more obvious during the 
research period. Compared with 2013, Moran's I increased in 2014, which indicates that the overall integration and development space of the three industries are more correlated.

Based on the idea of targeted poverty alleviation proposed in 2013, the project of targeted poverty alleviation was launched in 2014, and then the targeted poverty alleviation policy took place in full swing. Before the implementation of targeted poverty alleviation policy, each deeply impoverished area developed in its own way, lacking unified planning and top-level design, so the spatial correlation was relatively small. After the implementation of the targeted poverty alleviation policy, scientific and reasonable planning and guidance were made for the economic development of the deeply impoverished areas, and the integrated development level of the three industries was improved. With the continuous implementation of targeted poverty alleviation policies, the deeply impoverished areas have become the focus. Compared with the poverty-stricken areas, the causes of poverty in deeply impoverished areas are more complicated and diverse. In order to further implement the targeted poverty alleviation policy, the state has continuously improved the previous "targeted poverty alleviation" policy in order to meet the development needs of deeply impoverished areas. The spatial correlation between the integrated development of the three industries in the deeply impoverished areas decreased significantly in 2015 , which was ascribed to the poverty alleviation policy meeting the development needs of the impoverished areas. When the development potential of the deeply impoverished areas is fully tapped, it will take twice as much effort to further promote the development potential. In the crucial stage of poverty alleviation, the integrated development of the three industries in the deeply impoverished areas also embarked on a difficult road. In 2016, the global Moran's I of the industry convergence in deeply impoverished areas reached 0.2993 , which was also the maximum value in the research period. It shows that the integration of three industries in each deeply impoverished county showed a relatively high spatial correlation in the stage of poverty alleviation. This may be due to the mutual learning among the poor counties, or it may be due to the mutual hindrance among the poor counties. Moran scatter map and LISA cluster map can further explore the spatial correlation between the deeply impoverished areas.

\subsection{Regional Spatial Statistical Analysis on the Industry Integrated Development Level}

Moran scatter map and LISA cluster map were used to further explore the local spatial characteristics (relevance, the degree of difference, pattern distribution) of surrounding poverty-stricken counties.

\section{(1) Moran scatter diagram analysis}

The output of the Moran scatter diagram using GeoDa software can directly reflect the horizontal spatial correlation types and spatial distribution of the integrated development of the three industries in 169 deeply impoverished counties in China (as is shown in Figure 2).

As can be seen from Figure 1, the Moran index presents the characteristics of "wave-like advance and spiraling upward" in the four years. Deeply impoverished counties cluster in the first quadrant $(\mathrm{HH})$ and the third quadrant (LL).

It can be seen from the Moran scatter diagram (2013-2016) that the number of poverty-stricken counties in the HH quadrant rose from 39 in 2013 to 52 in 2016. It can be found via digital changes that after four years of development, the industry convergence in the deeply impoverished areas not only showed a healthy development trend but also actively drive the development of adjacent counties, which is mainly owing to the deepening of the national targeted poverty alleviation policy. In recent years, the state's industrial poverty alleviation policies for deeply impoverished areas, especially the basic strategy of precision poverty alleviation, focusing on industrial poverty alleviation, deepening the potential of industrial poverty alleviation, pinpointing industrial paths for poverty alleviation, and seeking characteristics that meet local realities Industry, and effectively promote the targeted poverty alleviation of industries in deeply impoverished areas. A series of industrial poverty alleviation strategies and plans have established a favorable environment for the industrial structure adjustment and regional economic and social development in deeply impoverished areas. 


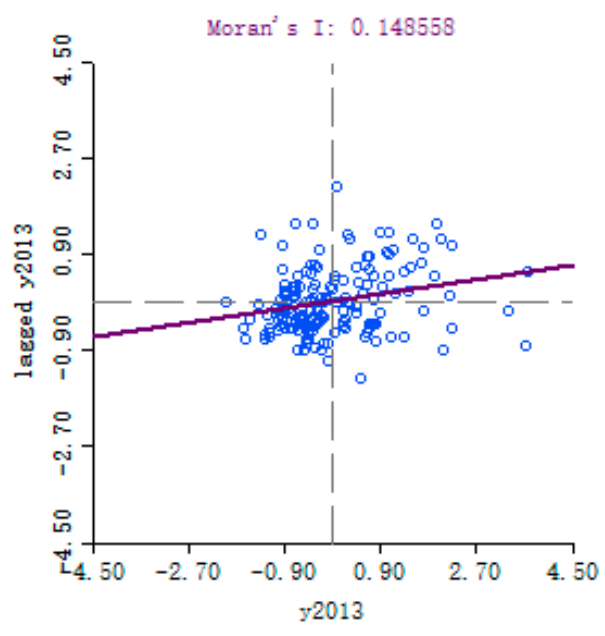

(a)

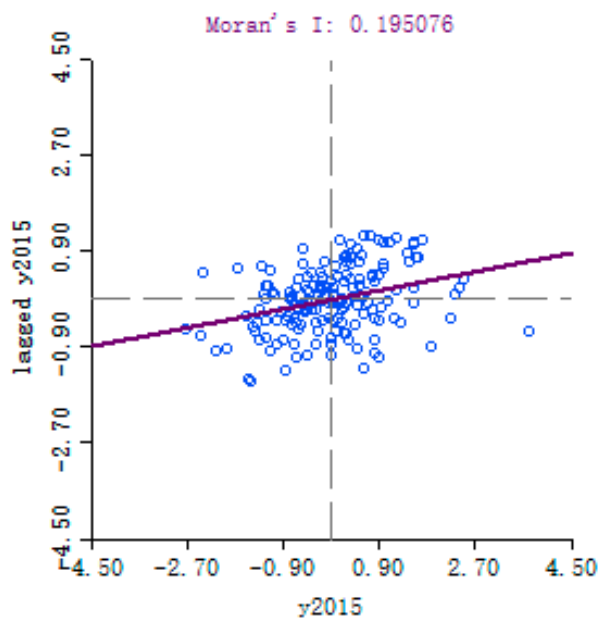

(c)

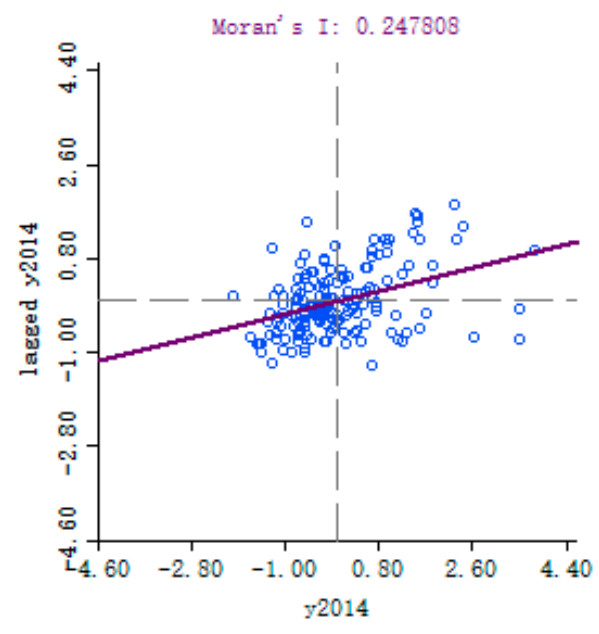

(b)

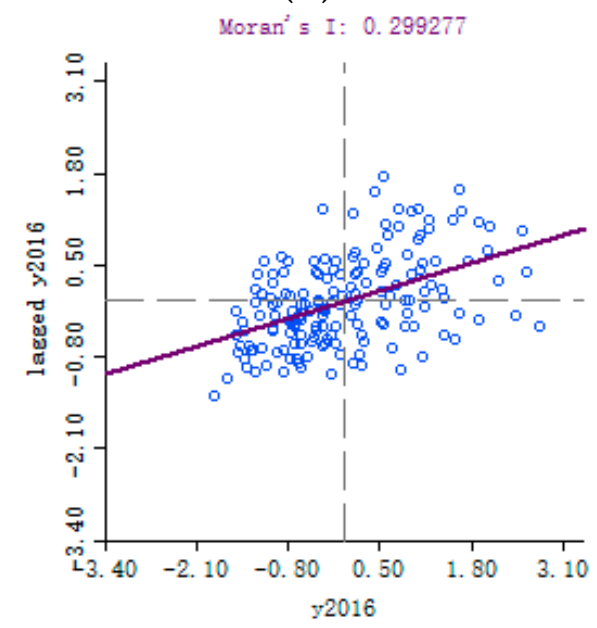

(d)

Figure 2. Moran scatter map of the industry integrated development level in deeply impoverished areas from year 2013 to 2016. (a) Year 2013. (b) Year 2014. (c) Year 2015. (d) Year 2016.

Pulan County, Zhongba County, Saga County, Gangcha County, Haiyan County, Ningnan County, Huili County, Huidong County, and Gongjue County, which had high industry convergence level in 2013, are at the quadrants of LL, LL, LL, LH, LH, HL, LH, LL, HL, LH, and LL, respectively. This may be due to the reason that the poverty alleviation policy did not fully play their role, or due to the reason that the potentiality had been explored. Therefore, when most poor counties significantly improved their situation, some of the counties that were initially in the HH quadrant dropped out of HH quadrant in the process of development. On the contrast, Atushi City (LH), Wuqia County (LL), Kashi City (LL), Shufu County (LL), Bange County (LH), Anduo County (HL), Dazi County (LH), Mozhugongka County (LH), Bomi (LH), Chayu County (HL), Fugong (LH), Lushui County (HL), Qusong County (LH), Yadong County (LL), Gangba County (LL), Dingjie (HL), Xide (HL), Qilian (HL), Yongjing (HL), Tongren County (LL), Guanghe County (HL), and Hezuo City (LH), which are within HH quadrant in 2013, joined in the HH quadrant in 2016. 
Changes in these poor counties have mainly benefited from targeted poverty alleviation policies. Poverty-stricken counties in the LL quadrant increased from 69 in 2013 to 72 in 2016. From the point of quantity, the number of counties in the LL quadrant has not changed, which is because the LL quadrant itself is at the low level of industry convergence, and there are little spatial differences between these counties with their adjacent counties. This situation may easily lead to a "low-low" situation. Those poor counties may be content with their status quo, and cannot make full use of the national welfare policy, which, in turn, results in the fact that they have been in the state of LL quadrant. The number of poor counties in the HL quadrant and the LH quadrant decreased by 12 and 4, respectively, from 2013 to 2016.

From the above analysis, it can be seen that the first quadrant and the third quadrant are always clustered with more poverty-stricken counties, but the first quadrant and the third quadrant are regions with obvious spatial differentiation reflecting spatial heterogeneity, which indicates that the level of three industry convergence in China's deeply impoverished areas presents the status of bipolar agglomeration in space. It is mainly because these regions have a worse natural ecological environment and a lower level of economic development. They have formed more closed spaces in the absence of infrastructure such as transportation and social networks, and it is more difficult for industrial integration to obtain the impetus for development, thus forming "space poverty" and internal vicious circle [57-59].

From 2013 to 2016, there has been spatial autocorrelation and spatial heterogeneity in the integrated development level of the Three industry convergence in the deeply impoverished areas of China. Although the agglomeration trend will change with the progress of the economy, it is also forming a relatively stable spatial pattern. Relevant studies have shown that economy, society, and politics are the main influencing factors for the solution of space poverty [60-62]. To eliminate this spatial heterogeneity, the traditional industrial balance must be broken, the space for industrial innovation must be opened up [63-65], and the promotion of three-industry integration is an effective mechanism to break this vicious circle [66-68].

(2) LISA cluster diagram analysis

Since Moran scatter map could not be used to judge whether the local correlation types and clusters of poor counties were significant (in statistics), LISA scatter map could make up for this. GeoDa software is used to acquire the LISA agglomeration chart of the integrated development level of three industry convergence in China's deeply impoverished areas (as is seen in Figure 3).

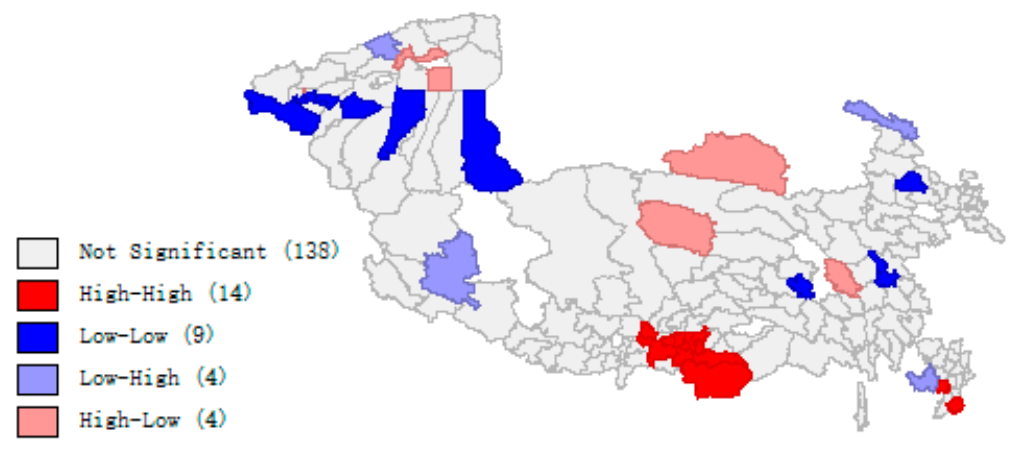

(a)

Figure 3. Cont. 


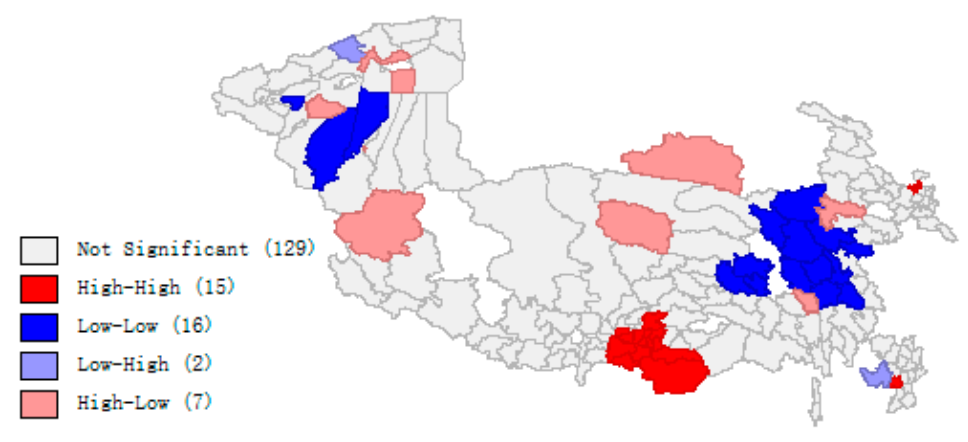

(b)

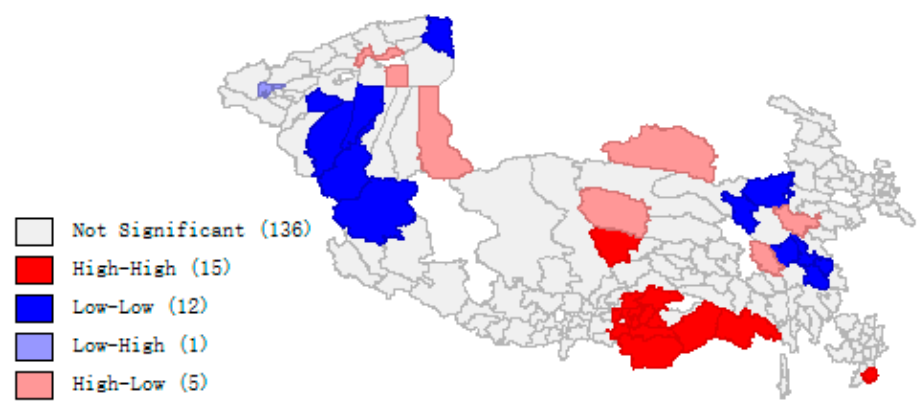

(c)

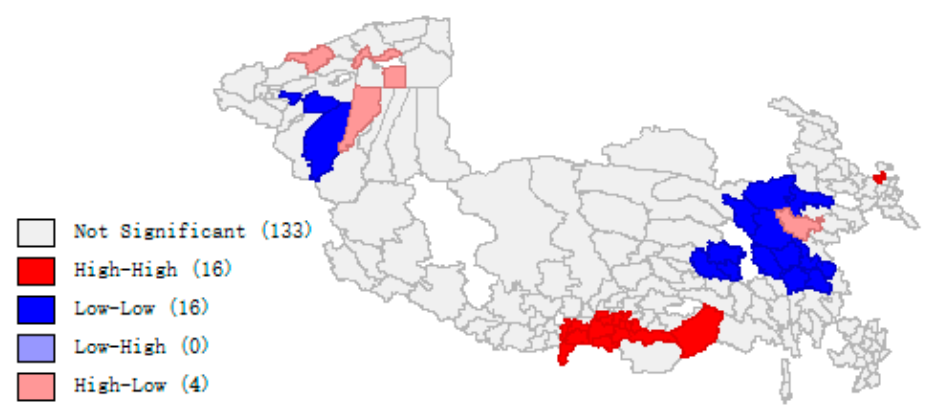

(d)

Figure 3. Local indicators of spatial association (LISA) agglomeration chart of the integrated development level of three industry convergence. (a) Year 2013. (b) Year 2014. (c) Year 2015. (d) Year 2016.

The deeply impoverished counties in the four quadrants above all passed the significance test of $1 \%$, and the LISA aggregation results during the observation period were summarized, as shown in Table 5 . 
Table 5. LISA clustering results.

\begin{tabular}{|c|c|c|c|c|}
\hline Year & $\mathbf{H H}$ & HL & LL & LH \\
\hline 2013 & $\begin{array}{l}\text { Cuona County, } \\
\text { Longzi County, } \\
\text { Cuomei County, } \\
\text { Qusong County, } \\
\text { Sangri County, } \\
\text { Naidong County, } \\
\text { Qiongjie County, } \\
\text { Dechang County, } \\
\text { Huidong County, } \\
\text { Zhanang County, } \\
\text { Langkazi County, } \\
\text { Gongga County, Renbu } \\
\text { County, Nimu County. }\end{array}$ & $\begin{array}{l}\text { Jiangda County, } \\
\text { Geermu County, } \\
\text { Aersu County }\end{array}$ & $\begin{array}{l}\text { Ganzi County, } \\
\text { Guinan County, } \\
\text { Leiwuqi County, } \\
\text { Aketao County, } \\
\text { Shule County, } \\
\text { Yuepuhu County, } \\
\text { Maigaiti County, } \\
\text { Moyu County, } \\
\text { Minfeng County }\end{array}$ & $\begin{array}{l}\text { Geji County, } \\
\text { Qilian County, } \\
\text { Wushi County, } \\
\text { Yanyuan County }\end{array}$ \\
\hline 2014 & $\begin{array}{l}\text { Cuona County, } \\
\text { Longzi County, } \\
\text { Qusong County, } \\
\text { Sangri County, } \\
\text { Mozhugognka County, } \\
\text { Naidong County, } \\
\text { Qiongiie County, } \\
\text { Cuomei County, } \\
\text { Luozha County, } \\
\text { Zhanang County, } \\
\text { Gongga County, } \\
\text { Qushui County, } \\
\text { Langkazi County, } \\
\text { Dechang County, } \\
\text { Linxia County }\end{array}$ & $\begin{array}{l}\text { Akesu County, } \\
\text { Maigaiti County, } \\
\text { Hetian County, } \\
\text { Ritu County, } \\
\text { Gongjue County, } \\
\text { Maqin County }\end{array}$ & $\begin{array}{l}\text { Yuepuhu County, } \\
\text { Pishan County, } \\
\text { Moyu County, } \\
\text { Nangqian County, } \\
\text { Leiwuqi County, } \\
\text { Dingqing County, } \\
\text { Chendu County, } \\
\text { Duoma County, } \\
\text { Shiqu County, } \\
\text { Dari County, } \\
\text { Banma County, } \\
\text { Jiangda County, } \\
\text { Dege County, } \\
\text { Ganzi County, } \\
\text { Baiyu County, } \\
\text { Xinlong County }\end{array}$ & $\begin{array}{l}\text { Wushi County, } \\
\text { Yanyuan County }\end{array}$ \\
\hline 2015 & $\begin{array}{c}\text { Cuona County, } \\
\text { Longzi County, } \\
\text { Motuo County, } \\
\text { Chayu County, } \\
\text { Lang County, } \\
\text { Jiacha County, } \\
\text { Gongbujiangda } \\
\text { County, Mozhugongka } \\
\text { County, Sangri County, } \\
\text { Qusong County, } \\
\text { Naidong County, } \\
\text { Zhanang County, } \\
\text { Cuomei County, } \\
\text { Anduo County, } \\
\text { Huidong County }\end{array}$ & $\begin{array}{l}\text { Dari County, } \\
\text { Jiangda County, } \\
\text { Geermu County, } \\
\text { Minfeng County, } \\
\text { Akesu County }\end{array}$ & $\begin{array}{l}\text { Chenduo County, } \\
\text { Duoma County, } \\
\text { Dege County, } \\
\text { Ganzi County, } \\
\text { Luhuo County, } \\
\text { Xinlong County, } \\
\text { Kuche County, } \\
\text { Moyu County, } \\
\text { Maigaiti County, } \\
\text { Pishan County, } \\
\text { Hetian County, } \\
\text { Ritu County }\end{array}$ & Shufu County \\
\hline 2016 & $\begin{array}{l}\text { Linxia County, } \\
\text { Motuo County, } \\
\text { Longzi County, } \\
\text { Qusong County, } \\
\text { Naidong County, } \\
\text { Qiongiie, Zhanang } \\
\text { County, Gongge } \\
\text { County, Qushui } \\
\text { County, Langkazi } \\
\text { County, Luozha } \\
\text { County, Cuomei } \\
\text { County, Jiangzi County, } \\
\text { Kangma County, } \\
\text { Bailang County, } \\
\text { Yadong County }\end{array}$ & $\begin{array}{l}\text { Dari County, } \\
\text { Akesu County, } \\
\text { Moyu County, } \\
\text { Aheqi County }\end{array}$ & $\begin{array}{l}\text { Maigaiti County, } \\
\text { Yuepuhu County, } \\
\text { Yecheng County, } \\
\text { Nangqian County, } \\
\text { Leiwuqi County, } \\
\text { Dingqing County, } \\
\text { Maduo County, } \\
\text { Maqin County, } \\
\text { Chenduo County, } \\
\text { Shiqu County, } \\
\text { Jiangda County, } \\
\text { Dege County, } \\
\text { Ganzi County, } \\
\text { Luhuo County, } \\
\text { Xinlong County, } \\
\text { Baiyu County }\end{array}$ & \\
\hline
\end{tabular}


In the region of the first quadrant (high-high), poor counties with a high integration level are surrounded by other poor counties with a high integration level. In other words, the industry convergence level of this county is high and has a relatively small difference with the industry convergence level of the adjacent counties. In the region of the second quadrant (high-low), poor counties with high integration level are surrounded by other poor counties with low integration level. In the region of the third quadrant (low-high), poor counties with low integration level are surrounded by other poor counties with a high integration level. In the region of the fourth quadrant (low-low), poor counties with low integration level are surrounded by other poor counties with low integration level.

The number of poverty-stricken counties in the four quadrants in Table 5 is mostly stable. Among them, the $\mathrm{HH}$ quadrant has the largest number of poor counties, followed by the LL quadrant. Most of deeply impoverished counties in Tibet fall into the HH quadrant, for the reason that those counties mainly gathered in southeast Tibet and are related to each other. The geographical position, natural resources, and environment are similar in these counties, and the development level resembles. The development of spiritual culture construction and Tibet tourism has enormous impetuses to local industry, economic development.

Deeply impoverished counties in Xinjiang and Sichuan Province mainly fall into the LL quadrant. Southern Xinjiang as a national hub, has a low industry convergence level due to the factors of language communication, cultural exchanges, and natural environment. If the level of integrated development of its own industries in a county is relatively low, it is hard to stimulate the development of surrounding areas. In most cases, it appears that these counties negatively influence each other from the perspective of industry convergence. Therefore, there is almost no correlation between the counties with a low level of industry convergence and their adjacent counties with a low level of industry convergence.

There are a small number of counties in quadrant HL. Poor counties in quadrant HL scatter in geographic position in 2013, and there are only deeply impoverished counties in Xinjiang left in quadrant HL in 2016. The development situation of poor counties in Southern Xinjiang differs. Some counties give priority to date growing, others to animal husbandry, and still others to tourism or traditional industries, which means even if the industry convergence level is relatively high, counties may not help each other forward, for they have different concerns. On the contrary, it is not easy for an impoverished county to maintain the average speed of growth and not be affected by the surrounding environment. The number of poor counties in the LH quadrant decreased from 4 in 2013 to 2 in 2014 to 1 in 2015, and there were no poor counties in the LH quadrant in 2016. It can be concluded that when a poor county with a low level of industry convergence is surrounded by poor counties with high level of industry convergence, the surrounding poor county can virtually drive and promote the development of the poor county with a lower level of industry convergence, so that finally, there is no poor county in the LH quadrant. In terms of coordinated development, the number of poor counties in the $\mathrm{HH}$ quadrant and the LL quadrant is increasing, while the number of poor counties in the HL quadrant and the LH quadrant is decreasing. Relevant research shows that the number of ethnic minority populations is also the cause of poverty accumulation. At present, China's deeply impoverished areas are mostly ethnic minority areas, which is more likely to form spatial poverty. At the same time, the formation of poverty is closely related to geographical location, and the improvement of economic conditions in poor areas will also be affected by the surrounding environment [69-71].

\section{Conclusions and Recommendation}

In this paper, the entropy value method, Moran's index, Lisa clustering graph are used to discuss the spatial distribution characteristics of the Three industry convergence development in 169 deeply impoverished counties from the global and local perspectives from 2013 to 2016 . The study found that the general level of three industry convergence in China's deeply impoverished areas is generally low, and there is great room for improvement. The industry convergence development has significant spatial correlation and spatial heterogeneity, and the phenomenon of bipolar agglomeration is significantly obvious. Based on the above conclusions, the following suggestions are proposed. 
Firstly, in view of the regional differences in the deeply impoverished counties, these counties should bring into full play its policy advantages to develop itself, and meanwhile, continuously improve the cross-regional cooperation benefit-sharing mechanism to narrow the differences among impoverished counties. It is more effective for the cooperation of neighboring counties they have a similar geographical location, natural conditions, and environment. Poverty-stricken counties can invest key funds in infrastructure such as catering, tourism, and logistics, so that the comparative merits of deeply impoverished areas can be freely utilized, and information, logistics, people, and capital flows can flow smoothly with the outside world. Focusing on the comparative advantages of different regions, the emphasis of industrial optimization and adjustment is also different: For counties and districts with relatively concentrated agricultural resources, they can focus on the construction of agricultural water conservancy facilities, agricultural product processing and storage, and logistics facilities. For areas with relatively abundant tourism resources, they should focus on transforming and upgrading tourist attractions, building branch roads that connect traffic arteries and attractions, and promoting the improvement of tourism supporting facilities such as catering and accommodation. In short, all counties and districts should improve their comprehensive development level, strengthen regional cooperation on the basis of giving full play to their policy benefits, and gradually reduce the differences in the integration and development of the three industries in the poor counties.

Secondly, at the national level, the state should continue to strengthen the adjustment and optimization of industrial structure, identify the integration growth points based on the economic foundation, resource endowment, industrial characteristics and other factors of the deeply impoverished areas, improve the comprehensive growth level of the industry, actively promote the three industry convergence development, and accelerate the economic transformation of those areas. A county (township, village) focuses on the development of a few characteristic industries with comparative advantages, which can give full play to economies of scale, create regional brands, resolve labor resettlement in situ, and achieve income growth. For example, Xinjiang adopts the strategy of "one county, one industry" for deeply impoverished counties, and chooses a leading product with large market potential, obvious regional characteristics, and high added value for each deeply impoverished county. The effect of poverty alleviation is obvious. With the continuous development of distinguishing industries, the comprehensive level of county and district industries will be improved, the three industries will be actively promoted and integrated, and the economic transformation in deep poverty areas will be accelerated.

Finally, from the perspective of the spatial pattern of three industry convergences, a variety of measures should be taken to strengthen cooperation between the poor counties with a higher level of industry convergence and the counties with a lower level of industry convergence. Each poor county should give full play to the mutual promotion effect of neighboring poor counties, reduce the hindrance to the development of neighboring poor counties with a high level of three industry convergence, and eliminate the mutual inhibition among the poor counties with a low level of three industry convergence. Poor counties in the HL quadrant can focus on industrial integration models, the main body cultivation, policy innovation, and investment and financing mechanisms. Each city (state) selects at least one county (city, district) and some townships, villages (communities) to carry out rural industrial integration. Develop pilot demonstrations to form a batch of replicate and scalable models as soon as possible. At the same time, it is necessary to summarize and discover advanced models of rural industrial integration and development in a timely manner, strengthen publicity and promotion, give full play to the role of demonstration, and promote the mutual development of poor counties in the HL quadrant.

Author Contributions: Conceptualization, N.Z. and P.L.; methodology, N.Z.; software, X.Z.; validation, N.Z., X.Z. and P.L.; investigation, X.Z. and P.L.; resources, N.Z. and P.L.; data curation, N.Z.; writing一original draft preparation, N.Z. and P.L.; writing-review and editing, N.Z., X.Z. and P.L.; visualization, N.Z.; supervision, P.L.; project administration, N.Z.; funding acquisition, N.Z. All authors have read and agreed to the published version of the manuscript. 
Funding: This work was supported by the Natural Science Foundation of China (Grant No. 41801119), the Royal Society and NSFC International Exchanges project (IEC \NSFC \170391), Social Science Foundation of China(Grant No. 18FGL003), Key Project of National Language Commission(ZDI135-67), China Postdoctoral Science Foundation funded project(Grant No. 2018M631220), Excellent Youth Foundation of Xinjiang Scientific Committee(Grant No. 2017Q071), Foundation of Shihezi University(RCSX201754), Ministry of Education Foundation of Humanities and Social Sciences (No. 19YJA630039).

Conflicts of Interest: The authors declare no conflict of interest.

\section{References}

1. Rachwał, T. Industrial restructuring in Poland and other European Union states in the era of economic globalization. Procedia Soc. Behav. Sci. 2011, 19, 1-10. [CrossRef]

2. Guo, J.H.; Guo, S.F. Construction and evaluation of the evaluation index system of cultural industry convergence innovation ability. Stat. Decis. 2019, 12, 62-65.

3. Nathan, R. Technological Change in the Machine Tool Industry, 1840-1910. J. Econ. Hist. 1963, 23, 414-443.

4. Hacklin, F.; Raurich, V.; Marxt, C. Implications of Technological Convergence on Innovation Trajectories: The Case of ICT industry. Int. J. Innov. Technol. Manag. 2005, 3, 313-330. [CrossRef]

5. Stefanie, B.; Jens, L. Industry Convergence and Its Implications for the Front End of Innovation: A Problem of Absorptive Capacity. Creat. Innov. Manag. 2007, 16, 165-175.

6. Greenstein, S.; Khanna, T. What does industry converge mean? In Competing in the Age of Digital Convergence; Yoffie, D.B., Ed.; Harvard Business School Press: Boston, MA, USA, 1997; pp. 201-226.

7. Stieglitz, N. Digital dynamics and types of industry convergence: The evolution of the handheld computer market. In The Industrial Dynamics of the New Digital Economy; Edward Elgar Publishing: Cheltenham, UK, 2003; pp. 179-208.

8. Chen, X. Industry Convergence and the Transformation of the Mobile Telecommunications System of Innovation. In Proceedings of the FITME ‘09, Second International Conference on Future Information Technology and Management Engineering, Sanya, China, 13-14 December 2009.

9. De, B.P.; Peilz, M. Innovation, convergence and the role of regulation in the Netherlands and beyond. Telecommun. Policy 2008, 32, 744-754.

10. Schmenner, R.W. Manufacturing, service, and their integrationaome. Int. J. Oper. Prod. Manag. Hist. Theory 2009, 29, 431-443. [CrossRef]

11. Liu, S.W. Research on the Integration Development of Shiyan's Cultural Industry and Tourism Industry Under the Background of Industrial Convergence. Int. Sci. Cult. Acad. Contacts 2018, 71, 638-644.

12. Hu, Y.B. Integration Development Analysis of Cross-border Electric Merchants and Logistics Industry Chain in the Background of Industrial Convergence. In Proceedings of the 2017 International Conference on Innovations in Economic Management and Social Science (IEMSS 2017), Hangzhou, China, 15-16 April 2017.

13. Hacklin, F.; Klang, D.; Baschera, P. Managing the Convergence of Industries: Archetypes for Successful Business Models. In Media and Convergence Management; Springer: Berlin/Heidelberg, Germany, 2013; pp. 25-36.

14. Hacklin, F.; Marxt, C.; Fahrni, F. An Evolutionary Perspective on Convergence: Inducing a Stage Model of Inter-Industry Innovation. Int. J. Technol. Manag. 2010, 49, 220-249. [CrossRef]

15. Richards, G. Cultural Tourism in Europe; Cab International: Wallingford, Oxfordshire, UK, 1996.

16. Gao, Z.; Lu, Z.G. An empirical study on the insutry convergence level of equipment manufacutring industry and high-tech service industry based on system coupling theory. J. Syst. Sci. 2019, 27, 63-68.

17. Chuanlei, W. Research on the Fusion of Informatization and Industrialization. Inf. Stud. Theory Appl. 2009, 32, 32-37.

18. Kang, X.; Li, L.; Aiting, T. Integration of Informatization and Industrialization, Technical Efficiency and Convergency. Manag. Rev. 2009, 10, 50-60.

19. Chandrashekar, A.; Schary, P.B. Toward the virtual supply chain: The convergence of IT and organization. Int. J. Logist. Manag. 1999, 10, 27-40. [CrossRef]

20. Zhang, Y.L.; Cui, Q. The integration evaluation between industrialization and informatization in China. Sci. Res. Manag. 2013, 34, 43-49.

21. Spring, M.; Araujo, L. Service, services and products: Rethinking operations strategy. Int. J. Oper. Prod. Manag. 2009, 5, 444-467. [CrossRef] 
22. Wang, F.; Pan, M.M. Industrial convergence, performance improvement and manufacturing industry growth: An empirical study based on panel data during 1998 to 2011. Stud. Sci. Sci. 2015, 33, 530-538.

23. Li, H.; Ding, X. Analysis on the development of equipment manufacturing and producer services in China. Stat. Decis. 2019, 35, 120-124.

24. Qi, L.Q.; Zhang, Q.N. Study on the network convergence influence factors of China's equipment manufacturing industry and producer service. Sci. Technol. Prog. Countermeas. 2018, 35, 64-71.

25. Min, L.; Shengzhong, Z.; Qunqi, W. The Game Analysis on the Main Factors of Logistics Industry Convergence. Econ. Manag. 2010, 5, 23-27.

26. Tomilina, E.P.; Glotova, I.I.; Kuzmenko, I.P. Development of integration processes in the traditional sectors of agriculture. Middle East. J. Sci. Res. 2013, 13, 178-182.

27. Uglitskikh, O.N.; Klishina, J.E. Modeling interregional inter-branch relations as an element of interaction between the branches of the agroindustrial complex. Middle East. J. Sci. Res. 2013, 13, 183-190.

28. Dan, H.Y.; Xu, W.M. The study on motives and effects of tourism industry and culture industry merge: In the case of Sichuan province. Ecol. Econ. 2015, 31, 110-113.

29. Gerasimov, A.N.; Gromov, Y.I.; Levchenko, S.A.; Grigorieva, O.P.; Oboturova, N.P. Features of the spatial socio-economic systems development in the North Caucasus Federal District. World Appl. Sci. J. 2014, 29, 699-705.

30. Lu, H.; Zhang, Y.R. An empirical analysis of the driving forces for the integrated development of tourism and cultural and creative industries. Econ. Bus. Res. 2015, 13, 124-126.

31. Wang, C.D. Regional industry convergence and the improvement of industrial R\&D efficiency-empirical study based on SFA and 30 provincial areas of China. China Soft Sci. 2017, 9, 94-103.

32. Xiao, J.Y.; Zheng, D.M. Modularity and industrial convergence: Coupling, mechanism, and effects. Sci. Technol. Manag. Res. 2012, 32, 13-15.

33. Färe, R.; Grosskopf, S.; Margaritis, D. Productivity growth and convergence in the European Union. J. Product. Anal. 2006, 25, 111-141. [CrossRef]

34. Gollop, F.M.; Monahan, J.L. A generalized index of diversification: Trends in US manufacturing. Rev. Econ. Stat. 1991, 73, 318-330. [CrossRef]

35. Rachwał, T. Structural changes in Polish industry after 1989. Geogr. Pol. 2015, 88, 575-605. [CrossRef]

36. Dominiak, J.; Rachwał, T. Chief development tendencies, structural changes and innovativeness of the industrial and service sectors in Poland. Quaest. Geogr. 2016, 35, 49-69. [CrossRef]

37. Rachwał, T. Research Issues of Structural Changes in Polish Industry in Geography of Industry. Stud. Ind. Geogr. Comm. Pol. Geogr. Soc. 2018, 32, 86-109. [CrossRef]

38. Kilar, W.; Rachwał, T. Changing Role of Industry in the Economy in the V4 Countries-A Regional Approach, 'Club of Economics in Miskolc'. Theory Methodol. Pract. 2014, 10, 45-54.

39. Gierańczyk, W.; Rachwał, T. Structural changes in the industry of Poland against the background of eastern European Union states. Quaest. Geogr. 2012, 31, 83-93.

40. Fisher, A.G. Clash of Progress and Security; Macmillan and Co. Limited: London, UK, 1935.

41. Clark, C. The Conditions of Economic Progress; McMillan: London, UK, 1940.

42. Kuznets, S. Modern economic growth: Findings and reflections. Am. Econ. Rev. 1973, 63, 247-258.

43. Porat, M.U. The Information Economy: Definition and Measurement; U.S. Government Printing Office: Washington, DC, USA, 1977.

44. Provisions on Division of Three Industries. In Gazette of the State Council of the People's Republic of China; 2003. Available online: http://www.stats.gov.cn/tjsj/tjbz/201804/t20180402_1591379.html (accessed on 16 January 2020).

45. Zhong, S.Y.; Li, Q.Y.; Xu, F. Spatial inequality and distributional dynamics of the development level of agricultural modernization in China. China Popul. Resour. Environ. 2016, 26, 145-152.

46. Zhang, Y.; Wang, X.J. Research on establishing index system and evaluating of agricultural modernization in Hubei province. Math. Pract. Theory 2016, 46, 154-159.

47. Jiang, H.M.; Wang, Z.H. Empirical analysis on the relationship among industrialization, urbanization, and agricultural moderization in Jilin Province. Sci. Geogr. Sin. 2012, 32, 591-595.

48. Zhong, J.J.; Wang, J. Correlation degree between China's logistics industry and three industries: From perspective of industry convergence. Technol. Econ. 2013, 32, 39-44. 
49. Wu, Y.M. Newly assessment of synthetical development levels of service industry of 31 provincial regions of China. China Soft Sci. 2000, 10, 53-57.

50. Jiang, H.; Zhang, K.J.; Zhang, H.Y.; Liu, Z.Y. Spatial-temporal difference and influence of China's three industrial convergence development. Econ. Geogr. 2017, 37, 105-113.

51. Levernier, W.; Partridge, M.D.; Rickman, D.S. The causes of regional variations in US poverty: A cross-county analysis. J. Reg. Sci. 2000, 40, 473-497. [CrossRef]

52. Rupasingha, A.; Goetz, S.J. The Causes of Enduring Poverty: An Expanded Spatial Analysis of the Structural Determinants of Poverty in the US (No. 22); Northeast Regional Center for Rural Development: State College, PA, USA, 2003.

53. Mallick, R.; Carayannis, E.G. Regional economic convergence in Mexico: An analysis by industry. Growth Chang. 1994, 25, 325-334. [CrossRef]

54. Coulombe, S.; Lee, F.C. Convergence across Canadian provinces, 1961 to 1991. Can. J. Econ. 1995, $28,886-898$. [CrossRef]

55. Guo, S.F.; Guo, J.H. Theoretical Analysis and Empirical Study of the Integration Innovation Driving Force in Cultural Industry. J. Nanjing Univ. Technol. 2019, 18, 89-98.

56. Zang, M.D.; Lou, Z.M.; Kong, J.J. Spatial-temporal differentiation of interprovincial water well-being performance in China. Resour. Environ. Yangtze Basin 2019, 28, 805-816.

57. Brooks, M.M. The Advantages of Comparative LISA Techniques in Spatial Inequality Research: Evidence from Poverty Change in the United States. Spat. Demogr. 2019, 7, 167-193. [CrossRef]

58. Fowler, C.S.; Kleit, R.G. The effects of industrial clusters on the poverty rate. Econ. Geogr. 2014, 90, $129-154$. [CrossRef]

59. Sjafii, A.; Mega, P.V.N. Investigating Economic Growth Impact on Poverty Reduction in East Java: Does Spatial Matter? Majalah Ekonomi 2011, 21, 1.

60. Rupasingha, A.; Goetz, S.J. Social and political forces as determinants of poverty: A spatial analysis. J. Socio-Econ. 2007, 36, 650-671. [CrossRef]

61. Gundersen, C. Are the effects of the macroeconomy and social policies on poverty different in nonmetro areas in the United States? Rural Sociol. 2006, 71, 545-572. [CrossRef]

62. Tacoli, C.; McGranahan, G.; Satterthwaite, D. Urbanization, poverty and inequity: Is rural-urban migration a poverty problem, or part of the solution? In The New Global Frontier; Routledge: Abingdon-on-Thames, UK, 2012; pp. 51-68.

63. Nijkamp, P. Regional development as self-organized converging growth. In Spatial Disparities and Development Policy; The World Bank: Washington, DC, USA, 2009; pp. 265-282.

64. Storper, M. The limits to globalization: Technology districts and international trade. Econ. Geogr. 1992, 68, 60-93. [CrossRef]

65. Howells, J. Regional systems of innovation. In Innovation Policy in a Global Economy; Cambridge University Press: Cambridge, UK, 1999; pp. 67-93.

66. Wang, M.Q.; Wang, N. Analysis of Anti-poverty Path Selecting in Western Ethnic PovertyBelt-Based on the Perspective of Space Poverty Theory. Guizhou Ethn. Stud. 2011, 32, 141-145.

67. HAO, X.Z.; LI, Y.M. Reasons analyses and solutions discussions of poverty in Nujiang prefecture. J. Yunnan Univ. Nat. Sci. Ed. 2007, 29, 166-172.

68. Goodland, R.; Daly, H. Why Northern income growth is not the solution to Southern poverty. Ecol. Econ. 1993, 8, 85-101. [CrossRef]

69. Partridge, M.D.; Rickman, D.S. Distance from urban agglomeration economies and rural poverty. J. Reg. Sci. 2008, 48, 285-310. [CrossRef]

70. Crandall, M.S.; Weber, B.A. Local social and economic conditions, spatial concentrations of poverty, and poverty dynamics. Am. J. Agric. Econ. 2004, 86, 1276-1281. [CrossRef]

71. Fontenot, K.; Singelmann, J.; Slack, T.; Siordia, C.; Poston, D.L., Jr.; Saenz, R. Understanding falling poverty in the poorest places: An examination of the experience of the Texas Borderland and Lower Mississippi Delta, 1990-2000. J. Poverty 2010, 14, 216-236. [CrossRef]

(C) 2020 by the authors. Licensee MDPI, Basel, Switzerland. This article is an open access article distributed under the terms and conditions of the Creative Commons Attribution (CC BY) license (http://creativecommons.org/licenses/by/4.0/). 